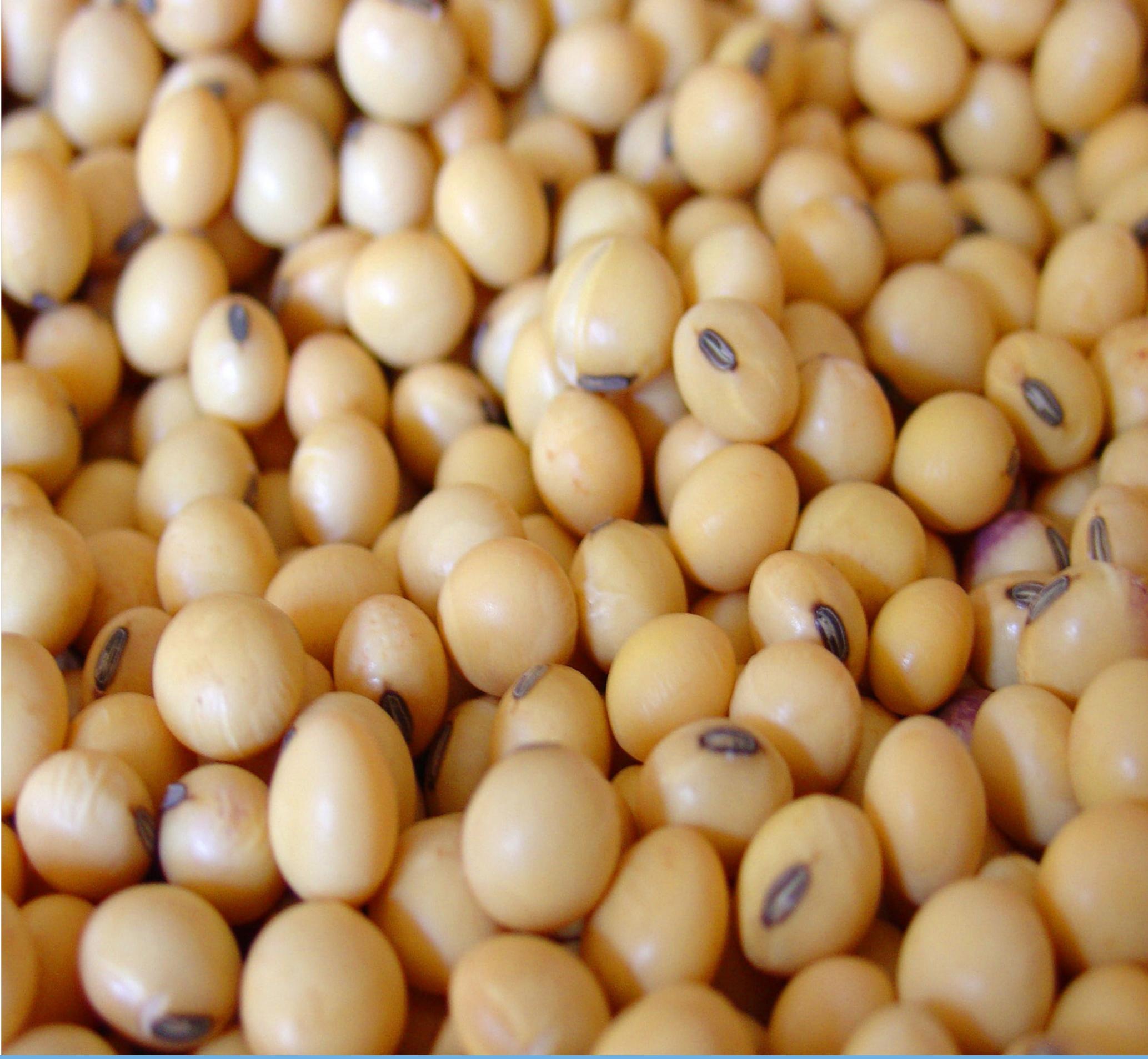

\title{
Factoren die het eiwitgehalte van sojabonen beïnvloeden
}

R.D. Timmer en C.L.M. de Visser

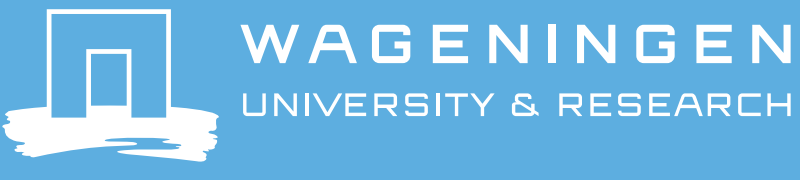




\section{Factoren die het eiwitgehalte van sojabonen beïnvloeden}

R.D. Timmer en C.L.M. de Visser $^{1}$

1 Wageningen University \& Research

Dit onderzoek is uitgevoerd door de Stichting Wageningen Research (WR), business unit Open Teelten, in het kader van het EU-project LegValue (projectnummer 3750353501).

WR is een onderdeel van Wageningen University \& Research, samenwerkingsverband tussen Wageningen University en de Stichting Wageningen Research.

Wageningen, mei 2020

Rapport WPR-833 
Timmer, R.D., Visser, C.L.M. de, 2020. Factoren die het eiwitgehalte van sojabonen beïnvloeden. Wageningen Research, Rapport WPR-833.

Dit rapport is gratis te downloaden op https://doi.org/10.18174/522308.

(c) 2020 Wageningen, Stichting Wageningen Research, Wageningen Plant Research, Business unit Open Teelten, Postbus 430, 8200 AK Lelystad; T 03202911 11; www.wur.nl/plant-research

KvK: 09098104 te Arnhem

VAT NL no. 8113.83.696.B07

Stichting Wageningen Research. Alle rechten voorbehouden. Niets uit deze uitgave mag worden verveelvoudigd, opgeslagen in een geautomatiseerd gegevensbestand, of openbaar gemaakt, in enige vorm of op enige wijze, hetzij elektronisch, mechanisch, door fotokopieën, opnamen of enige andere manier zonder voorafgaande schriftelijke toestemming van Stichting Wageningen Research.

Stichting Wageningen Research is niet aansprakelijk voor eventuele schadelijke gevolgen die kunnen ontstaan bij gebruik van gegevens uit deze uitgave.

Rapport WPR-833 


\section{Inhoud}

$\begin{array}{ll}\text { Samenvatting } & 5\end{array}$

1

Inleiding

7

2

$\begin{array}{ll}\text { Fysiologie } & 9\end{array}$

2.1 Stadia van gewasontwikkeling $\quad 9$

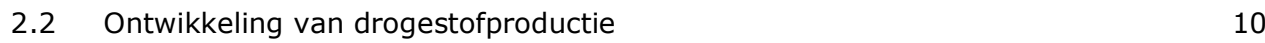

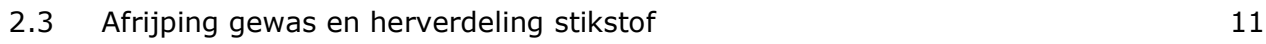

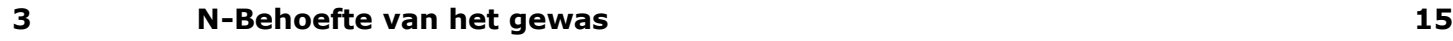

$\begin{array}{lll}3.1 & \text { Stikstofknolletjes } & 15\end{array}$

$\begin{array}{lll}3.2 & N \text {-bemesting } & 18\end{array}$

4

$\begin{array}{ll}\text { Opbrengstniveau } & 21\end{array}$

$\begin{array}{llr}5 & \text { Weersomstandigheden groeiseizoen } & 23\end{array}$

$\begin{array}{ll}\text { Literatuur } & 25\end{array}$ 


\section{Samenvatting}

Het eiwitgehalte is een belangrijk aspect bij de afzet van soja. Zowel voor food als voor feed wordt gestreefd naar een zo hoog mogelijk gehalte. Een goede partij soja heeft een eiwitgehalte van minimaal 38\% maar liefst meer dan $42 \%$. Het eiwitgehalte van in Nederland geteelde soja varieert sterk van jaar tot jaar en van locatie tot locatie. Vaak is niet duidelijk waarom in het ene geval het eiwitgehalte hoog is ( $>42 \%$ ), en in het andere geval blijft steken op slechts $35-37 \%$. Er is daarom een literatuurstudie uitgevoerd naar factoren die van invloed zijn op het eiwitgehalte van soja zoals ras, enting met Rhizobiumbacteriën, stikstofbemesting, het opbrengstniveau en de weersomstandigheden tijdens het groeiseizoen.

In de $\mathrm{N}$-behoefte van een sojagewas wordt voorzien door N-binding uit de lucht (via de wortelknolletjes) en stikstofopname uit de bodem (voorraad en mineralisatie). Van de totale $\mathrm{N}$ behoefte is soja in staat om ongeveer $50 \%-75 \%$ te halen uit $\mathrm{N}$-binding, de rest moet komen uit de bodem. En daarnaast kan ook door een kunstmestgift stikstof aan het gewas worden gegeven.

De bacteriën waarmee soja in symbiose leeft zijn van nature niet aanwezig in de Europese bodems en moeten geïnoculeerd worden bij het zaaien. Veelal gebeurt dit via een behandeling van het zaaizaad. Entingsproduct, dosering, toepassingsmethode en bodemtemperatuur spelen een rol bij de ontwikkeling van de wortelknolletjes. Een goed geslaagde enting is essentieel voor het behalen van een hoge opbrengst en een hoog eiwitgehalte. In geen enkel artikel kon echter iets gevonden worden over het optimale aantal wortelknolletjes per plant.

Belangrijker dan het aantal knolletjes en het (drogestof)gewicht van de knolletjes lijkt de verdeling van de knolletjes over het wortelstelsel. Bij een enting via zaaizaad, zoals in Nederland, worden veruit de meeste knolletjes gevonden aan de hoofdwortels(s) en in de laag $0-5 \mathrm{~cm}$. Knolletjesvorming aan de zijwortels en diepere wortels zouden wel eens essentieel kunnen zijn voor een optimale $\mathrm{N}$-fixatie; zeer waarschijnlijk zijn ze van groot belang tijdens de (latere) zaadvullingsfase, een periode waarin de vraag naar stikstof op z'n grootst is. Het inoculeren van de grond i.p.v. het zaad, of als aanvulling op het zaad, lijkt de $\mathrm{N}$-fixatie aanzienlijk te kunnen verhogen.

Veel artikelen die onderzoek naar het effect van $\mathrm{N}$-bemesting bij soja beschrijven gaan alleen in op het effect op de opbrengst. Over het effect op (het verhogen van) het eiwitgehalte is veel minder informatie te vinden. Ten aanzien van de opbrengst is de algemene conclusie dat de $\mathrm{N}$-binding in het merendeel van de situaties in staat is om in de $\mathrm{N}$-behoefte van het gewas te voorzien. Echter ook enkele onderzoekers geven aan dat er bij een hoog opbrengstniveau wel een N-tekort kan optreden tijdens de peulvulling omdat de $\mathrm{N}$-binding (samen met $\mathrm{N}$-beschikbaarheid vanuit de bodem) de sterke $\mathrm{N}$-behoefte niet kan dekken. Een $\mathrm{N}$-bemesting in die gewasfase zou zowel voor de opbrengst als voor het eiwitgehalte een (rendabel) positief effect hebben.

Literatuur over de relatie tussen opbrengst en eiwitgehalte geeft een wat wisselend beeld. Er wordt enerzijds gemeld dat hogere opbrengsten niet tot significant lagere eiwitgehalten leidt maar anderzijds zijn er meerdere artikelen die aangeven dat een hoge opbrengst wel gecorreleerd is met een lager eiwitgehalte. Over het algemeen wordt er vanuit gegaan dat er een negatieve relatie is tussen opbrengst en eiwitgehalte. Hierdoor is het in de veredeling lastig om te selecteren op rassen met een hoog eiwitgehalte, aangezien de opbrengst van deze rassen lager is.

De diverse studies naar de invloed van weerfactoren, zoals temperatuur, zonlicht en neerslag op de groei en samenstelling van sojabonen laten een wisselend beeld zien. Sommige studies rapporteren een toename van het oliegehalte bij een hogere temperatuur zonder een effect op het eiwitgehalte, terwijl andere studies een positieve, lineaire relatie laten zien tussen temperatuur en eiwitgehalte, maar een negatieve relatie tussen temperatuur en oliegehalte. Weer andere studies vinden een 
positief effect van hogere temperaturen op zowel het eiwitgehalte als het oliegehalte. Dit gaat dan wel samen met een lage(re) opbrengst.

Tijdens de zaadvulling en afrijping van het gewas neemt de activiteit van de wortelknolletjes af en vind er redistributie plaats van stikstof uit de bladeren en peulen naar het zaad. Rassen met een hoger eiwitgehalte blijken echter in staat te zijn om langer door te gaan met de N-fixatie tot het R6-stadium (full seed). Op deze manier zijn ze in staat om meer stikstof te binden in een later gewasstadium en het eiwitgehalte zo te verhogen. Een grotere hoeveelheid $N$ in het afgerijpte zaad bleek ook niet gerelateerd aan een grotere hoeveelheid $\mathrm{N}$ in de vegetatieve massa aan het begin van de zaadvulling. Ofwel, de redistributie lijkt niet de enige reden te zijn van een grotere hoeveelheid opgeslagen stikstof in het zaad, maar meer een hogere $\mathrm{N}$-opname uit de bodem en/of een langer doorgaande $\mathrm{N}$-binding gedurende de zaadvullingsperiode.

Het eiwitgehalte van soja wordt bepaald door het ras, de teeltwijze, de groeiomstandigheden, de (activiteit en de plaats op het wortelstelsel van de) wortelknolletjes, de opbrengst en de interactie tussen al deze factoren. Dit proces is vermoedelijk dermate complex dat er geen duidelijke relaties lijken te zijn met een van de afzonderlijke factoren. 


\section{$1 \quad$ Inleiding}

Het eiwitgehalte is een belangrijk kwaliteitsaspect bij de afzet van soja. Zowel voor food als voor feed wordt gestreefd naar een zo hoog mogelijk gehalte. Veelal is ook de prijs van soja gekoppeld aan het eiwitgehalte. Een goede partij soja heeft een eiwitgehalte van minimaal 38\% maar liefst $40 \%$ of hoger in geval van een toepassing als veevoer, maar minimaal $42 \%$ gebruikt voor humane consumptie. Het eiwitgehalte van in Nederland geteelde soja varieert sterk van jaar tot jaar en van locatie tot locatie zonder een duidelijke relatie met opbrengst (figuur 1.1 en figuur 1.2). Vaak is niet duidelijk waarom in het ene geval het eiwitgehalte van een partij soja hoog is en voldoet aan de gestelde normen voor humane consumptie ( $>42 \%$ ), en in het andere geval blijft steken op slechts $35-37 \%$ en alleen verkocht kan worden als veevoer.

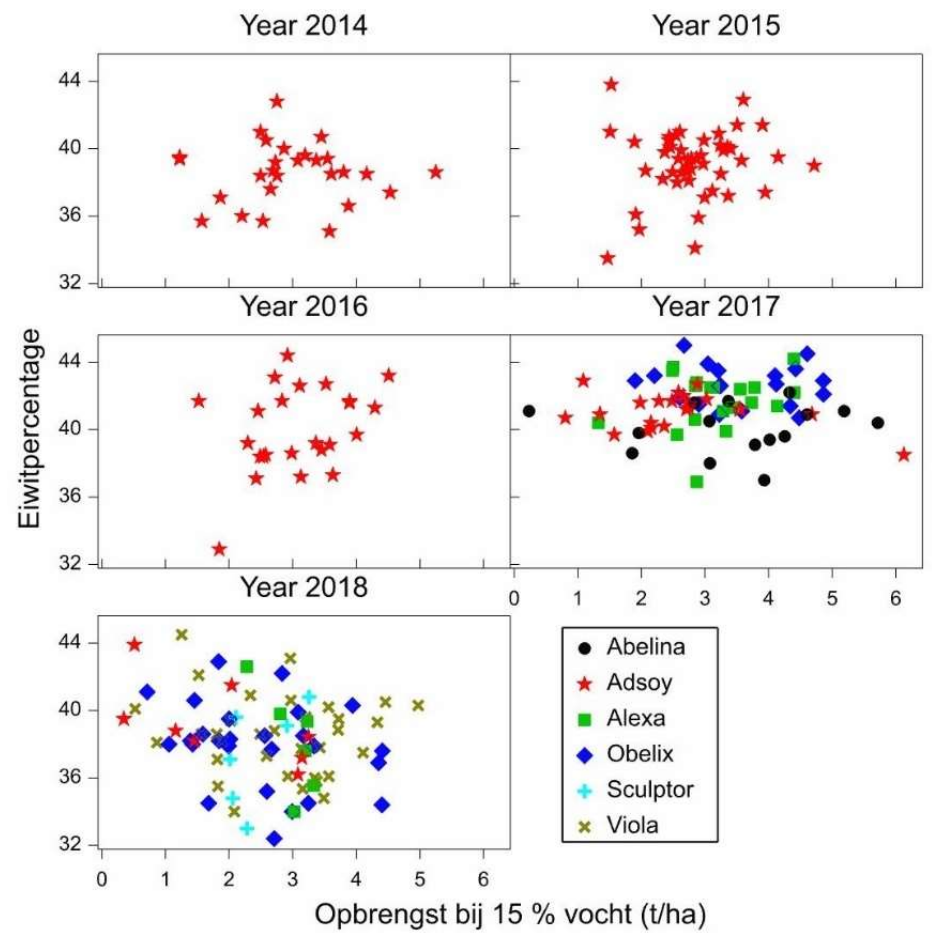

Figuur 1.1 Relatie tussen eiwitgehalte en opbrengst bij soja van Nederlandse sojatelers in de periode2014-2018. 


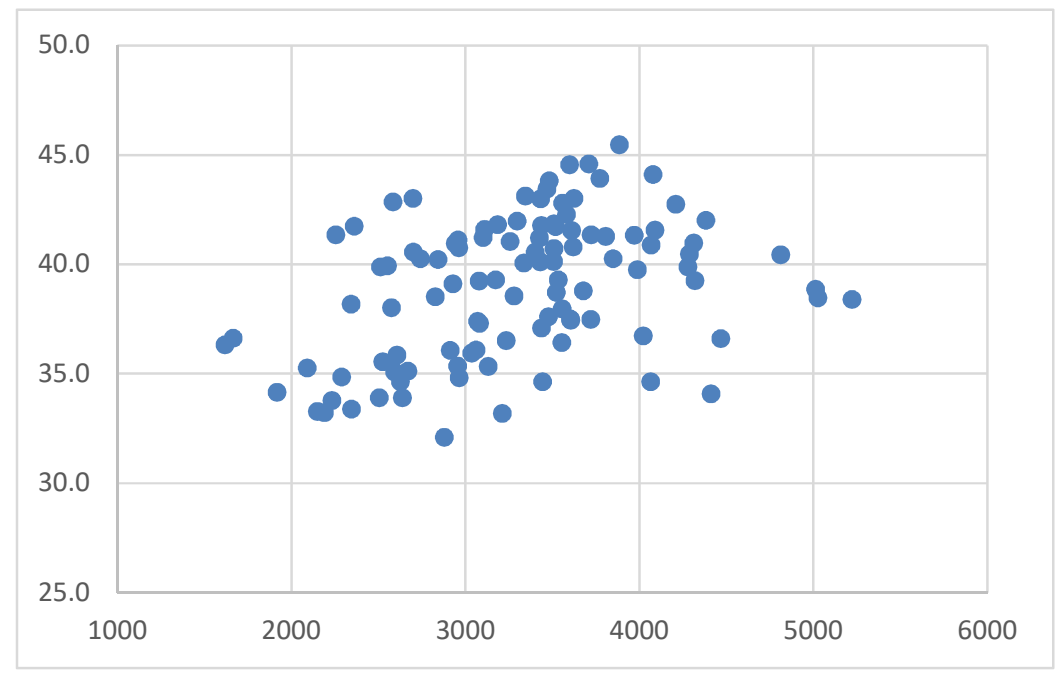

Figuur 1.2 Relatie tussen eiwitgehalte en opbrengst in soja rassenproeven in Nederland in de periode 2014-2019.

Ook in landen waar van oudsher grote hoeveelheden soja worden geproduceerd (VS, Brazilië, Argentinië) fluctueert het eiwitgehalte sterk. Het meerjarige gemiddelde eiwitgehalte in de VS ligt rond de $40 \%$ maar kan variëren per ras, regio en jaar van 30\% tot wel $48 \%$ (Brumm and Hurburgh, 2006).

Om het eiwitgehalte te kunnen sturen is het belangrijk voor een teler te weten welke factoren van invloed zijn. Bekend is dat er significante verschillen zijn tussen rassen. De genetica bepaalt voor een belangrijk deel de hoogte van het eiwitgehalte. Daarnaast speelt ook de ontwikkeling van de zogenaamde stikstofknolletjes aan de wortels een rol. Deze knolletjes zorgen ervoor dat de plant in z'n eigen stikstofbehoefte kan voorzien via de binding van stikstof uit de lucht. Een goede stikstofvoorziening is belangrijk voor zowel de opbrengst als het eiwitgehalte. Ook de groeiomstandigheden gedurende het seizoen (temperatuur, vocht, licht, beschikbaarheid van N, P, K en andere elementen) zullen een rol spelen bij de vorming en opslag van eiwit (en olie) in het zaad.

Omdat het eiwitgehalte van soja zo'n cruciale rol speelt in de marktwaarde van het product, het eiwitgehalte sterk varieert van jaar tot jaar en van plaats tot plaats en het niet goed bekend is hoe het eiwitgehalte tot stand komt, is een literatuurstudie is gedaan naar de belangrijkste bepalende factoren die van invloed zijn. Hierbij kan gedacht worden aan rassenkeuze, enting met Rhizobiumbacteriën, stikstofbemesting, het opbrengstniveau en de weersomstandigheden tijdens het groeiseizoen. De eerste drie factoren hebben met de teelt te maken en zijn te gebruiken om te sturen in de richting van een hoog eiwitgehalte. De twee andere factoren kunnen vooral verklarend zijn waarom het eiwitgehalte in bepaalde jaren of situaties hoog of juist laag is.

Zoals bekend, en hiervoor genoemd, speelt de genetica (ras) een hele belangrijke rol bij de hoogte van het eiwitgehalte. De literatuurstudie heeft zich hierop echter niet specifiek gericht. Een teler kan hiervan gebruik maken door een ras te kiezen met een (relatief) hoog eiwitgehalte. Er zijn rassen die vrijwel altijd een relatief hoog eiwitgehalte hebben en andere die veelal relatief laag in eiwit zijn. Maar er kan ook interactie zijn tussen rassen en andere eiwit-beïnvloedende factoren. Als hiertoe aanleiding is, zal in dit rapport de factor ras ook ter sprake komen bij de andere genoemde factoren. 


\section{Fysiologie}

\section{$2.1 \quad$ Stadia van gewasontwikkeling}

De ontwikkeling van een sojaplant is te verdelen in vegetatieve groeistadia ( $V$-stadia) en generatieve groeistadia (R-stadia) (figuur 2.1). De vegetatieve fase (V) duurt vanaf de opkomst tot de bloei. De verschillende stadia tijdens de vegetatieve periode worden wel aangegeven als V1, V2, V3 etc. Hierbij staat het nummer achter de letter $\mathrm{V}$ voor het aantal knopen aan de stengel met daarop een volledig ontwikkeld (samengesteld) blad. Alleen de eerste twee stadia tijdens de vegetatieve fase worden afwijkend gecodeerd, namelijk met VE (opkomst, de zaadlobben komen boven de grond) en VC (de eerste twee bladeren -welke enkelvoudig zijn- zijn volledig ontvouwen). Het aantal vegetatieve stadia dat zich ontwikkelt, is afhankelijk van ras en groeiomstandigheden.

\author{
Vegetatieve stadia \\ $\mathrm{VE}=$ opkomst \\ $\mathrm{VC}=$ zaadlobben ontvouwd \\ $\mathrm{V} 1$ = eerste knoop zichtbaar \\ V2 = tweede knoop zichtbaar \\ $\mathrm{V} 3=$ derde knoop zichtbaar \\ V4 = vierde knoop zichtbaar \\ $\mathrm{V} 5=$ vijfde knoop zichtbaar \\ $V(n)=n$-de knoop zichtbaar
}

\author{
Generatieve stadia \\ $\mathrm{R} 1$ = start bloei \\ $\mathrm{R} 2$ = volle bloei \\ R3 = begin vorming peul \\ R4 = peul volledig gevormd \\ R5 = start zaadvorming in de peul \\ R6 = zaden volledig gevormd in de peul \\ R7 = rijping van de peulen gestart \\ R8 = volledige rijpheid
}

Figuur 2.1 Ontwikkelingsstadia van soja.

De voortplantingsfase $(R)$ duurt van de bloei tot de afrijping. De verschillende gewasstadia worden vastgesteld op basis van de ontwikkeling van de bloemen, peulen en het zaad in de peulen (figuur 2.2).

Dit systeem geeft een nauwkeurige indeling van de verschillende fasen van een sojaplant. Echter, niet alle planten op een sojaperceel zullen tegelijkertijd in dezelfde fase van ontwikkeling zijn. Er is daarom gedefinieerd dat een fase pas bereikt is wanneer minimaal $50 \%$ van de planten in deze $\mathrm{V}$ - of $\mathrm{R}$-fase verkeert.

Bloei

De lengte van de periode van zaaien tot begin bloei is sterk afhankelijk van de temperatuur. Wanneer vroeg gezaaid wordt ( $3^{\mathrm{e}}$ week april) is deze periode beduidend langer dan wanneer laat wordt gezaaid ( $3^{\mathrm{e}}$ week mei).

Wortelknolletjes

Gelijktijdig met de bovengrondse ontwikkeling van de plant ontwikkelen zich ondergronds de wortels en wanneer deze gepenetreerd worden door de bacterie Bradyrhizobium japonicum ontwikkelen zich hieraan de $\mathrm{N}$-bindende wortelknolletjes. De activiteit van de bacterie is afhankelijk van de bodemtemperatuur maar meestal beginnen binnen een week na opkomst de eerste knolletjes zich al te ontwikkelen. De actieve N-binding begint echter pas vanaf het V2/V3-stadium. Het aantal knolletjes en de N-binding neemt vanaf dat moment toe en de maximale N-binding vindt plaats tussen R3 en R5. In de fase R5-R7 neemt de activiteit van de knolletjes en daarmee de N-binding af.

Gedurende het gehele seizoen worden er nieuwe knolletjes gevormd maar dit proces eindigt tijdens de zaadvullingsfase (R5/R6). Ongeveer 4 weken na de infectie (penetratie van de wortel) zijn de knolletjes volgroeid en op hun maximale grootte. En ongeveer 2 maanden na de infectie beginnen de knolletjes te degenereren en verliezen ze hun activiteit. Actieve stikstofknolletjes zijn bij doorsnijden rozerood van binnen; knolletjes die grijszwart van binnen zijn, zijn niet langer actief. 


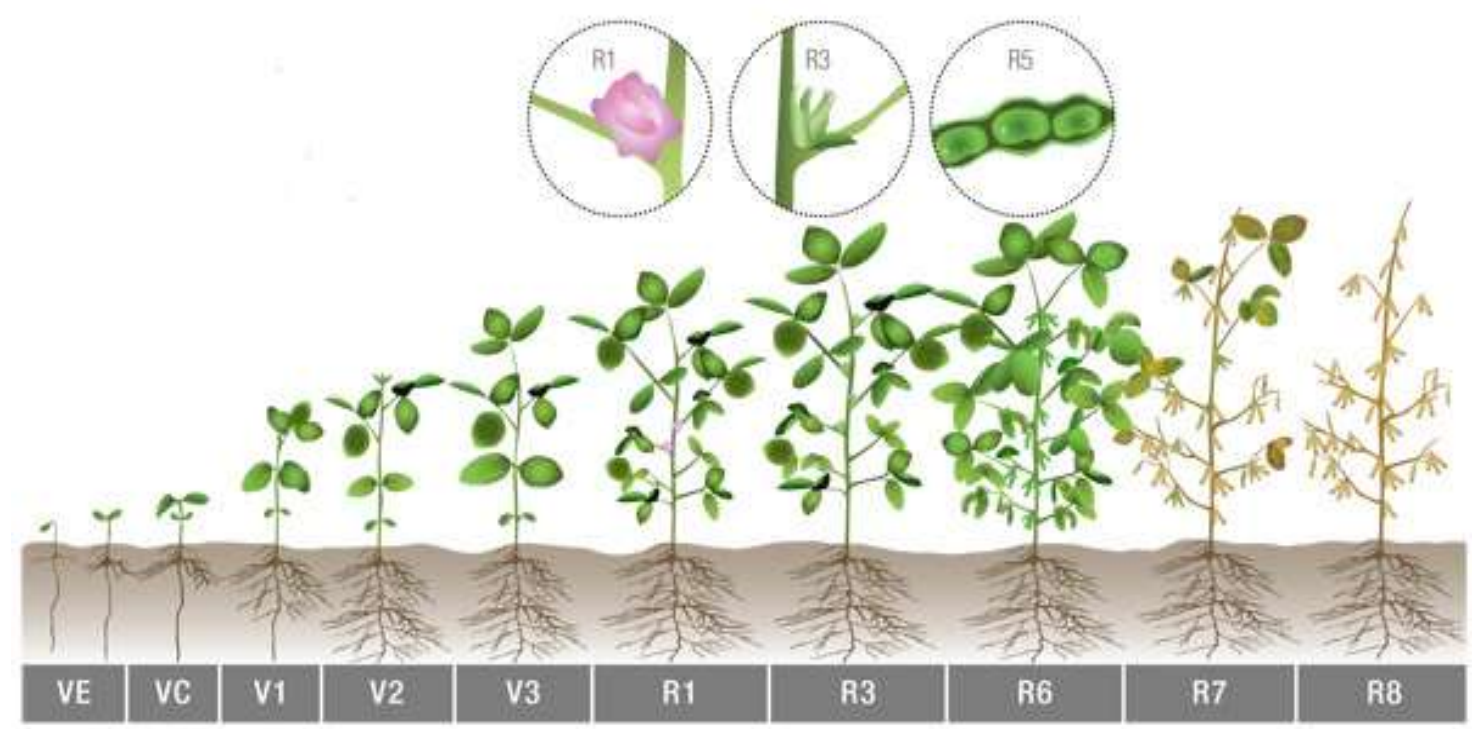

R1 begin bloei; 1 open bloem op de hoofdstengel

R2 volle bloei; open bloem op 1 van de twee bovenste knopen op de hoofdstengel.

R3 begin peulvorming, een peul van $0,5 \mathrm{~cm}$ lang op 1 van de 4 bovenste knopen op de hoofdstengel.

R4 volledige peulvorming, een peul van $7-10 \mathrm{~cm}$ lang op 1 van de 4 bovenste knopen op de hoofdstengel

R5 begin zaadvorming; een boon van $0.3 \mathrm{~cm}$ in een peul op 1 van de 4 bovenste knopen op de hoofdstengel

R6 volledige zaadvorming, peul bevat een volledig ontwikkelde boon die de peul vult op 1 van de 4 bovenste knopen op de hoofdstengel.

R7 begin afrijping, één peul op de hoofdstengel die een afgerijpte kleur heeft.

R8 volledig afgerijpt, 95\% van de peulen zijn afgerijpt.

Figuur 2.2 Beschrijving van generatieve fasen van de sojaplant (bron: http://danal.bjgmctb.org/soybean-plant-growth-stages/soybean-growth-stages.htmI).

\subsection{Ontwikkeling van drogestofproductie}

Een review over groei- en ontwikkeling van soja is gegeven door Shibles et al. (1975). Deze auteurs geven aan dat de snelheid van gewasgroei recht evenredig is met de hoeveelheid onderschept licht (mits er geen water stress is). Na een langzame start neemt het aantal bladeren bij soja snel toe en de LAI bedraagt op het hoogtepunt (einde bloei) $5-8 \mathrm{~m}^{2} / \mathrm{m}^{2}$. Daarna gaan de bladeren langzaam verouderen/vergelen en afvallen en neemt de LAI af tot 4-6 m2/m2. De snelheid van gewasgroei (totale drogestof accumulatie in het gewas) bleek verschillend per ras en bedroeg volgens de auteurs zo'n 88-149 kg ds/ha/dag. Ondanks dit verschil in snelheid van drogestofproductie van het totale gewas rapporteerden de auteurs geen verschil in de toename van de drogestof in de bonen. Deze bedroeg voor verschillende rassen ca. $100 \mathrm{~kg} \mathrm{ds} / \mathrm{ha} / \mathrm{dag}$. Verschillen in opbrengst tussen rassen konden meer worden toegewezen aan verschillen in lengte van de boonvullingsperiode dan van de snelheid van drogestofgroei per dag.

De toename van de drogestof productie is nagenoeg lineair in de periode tussen midden bloei en einde zaadvulling, met een maximale vegetatieve biomassa in de fase van midden zaadvulling (Figuur 2.3). Tijdens de tweede helft van de zaadvullingsperiode neemt de hoeveelheid drogestof in de vegetatieve delen (bladeren, peulen en stengels) af, hetgeen het gevolg is van o.a. translocatie van voedingsstoffen naar de bonen. Dit wordt goed geïllustreerd door de N-gehaltes in de verschillende plantenonderdelen in de loop van het seizoen. De stikstof in blad, stengel en peulen nemen aanvankelijk toe om daarna af te nemen ten faveure van de stikstof in de zaden. Dit komt ook overeen met de afnemende activiteit van de stikstofknolletjes vanaf begin zaadvorming. 

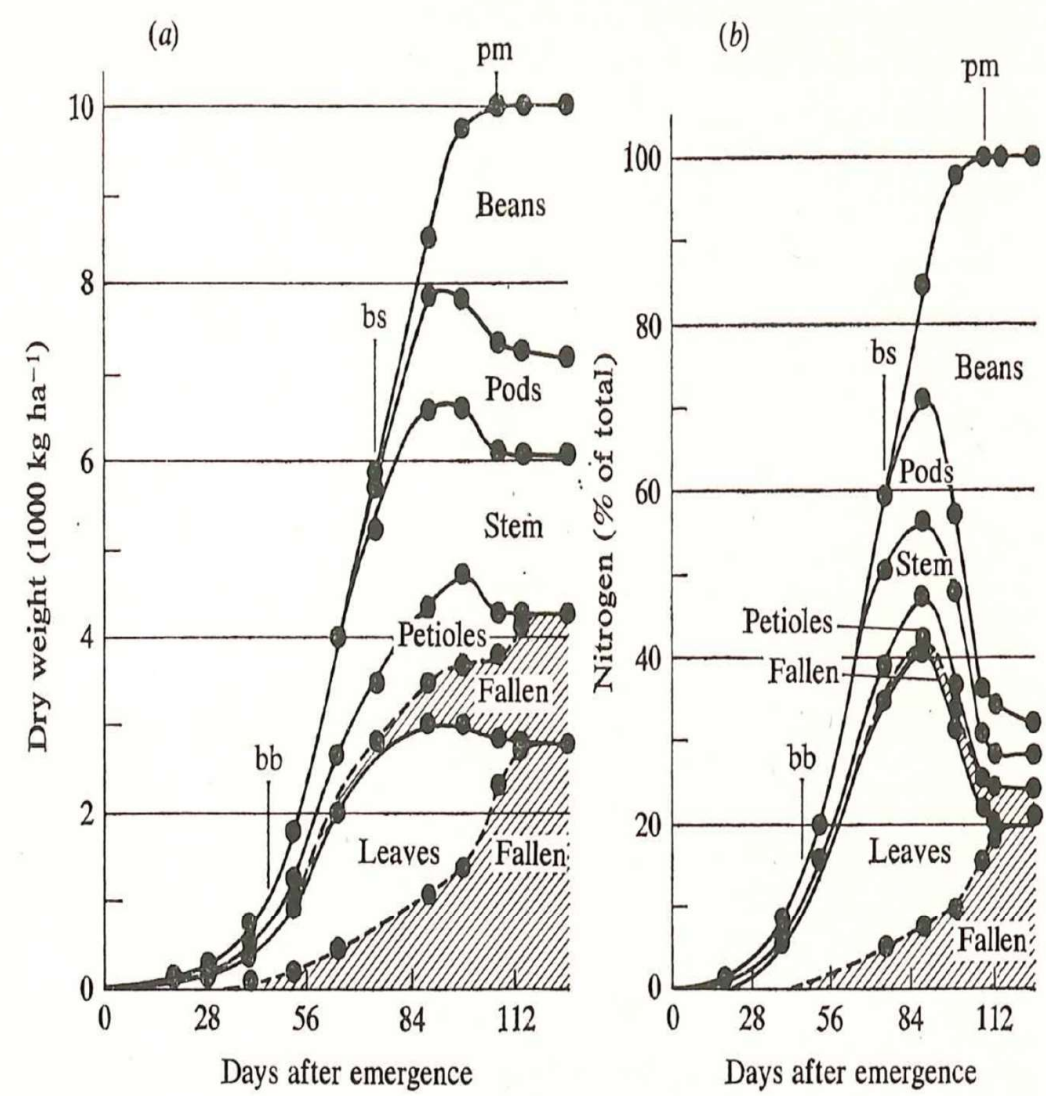

Figure 6.2. Cumulative dry weight $(a)$ and relative amount of nitrogen $(b)$ in above-ground plant parts during the growing season. $\mathrm{bb}$, bs and $\mathrm{pm}$ indicate beginning bloom, beginning seed-filling and physiological maturity stages respectively. The shaded portions indicate abscised petioles and leaves. (Adapted from Hanway and Weber, 1971b, 1971d.)

Figuur 2.3 Drogestofverdeling van drogestof en stikstof gedurende het seizoen tussen organen bij soja gedurende de groeit (bron: Shibles et al, 1975).

\subsection{Afrijping gewas en herverdeling stikstof}

De veroudering van een sojagewas begint kort na begin zaadvulling (R5-R6) zoals ook geïllustreerd wordt in figuur 2.3. De fotosynthese neemt af met $60 \%$ in 3 weken tijd en ook het eiwitgehalte en het chlorofyl in het loof halveren in die periode. Onderzoek van Sesay and Shibles (1980) laat zien dat via een bladbemesting op dat moment de gehaltes aan N, P en K in het blad kunnen worden verhoogd maar dat dit het moment van verouderen niet vertraagt. Het onderzoek geeft daarmee aan dat de veroudering van soja niet (uitsluitend) gerelateerd lijkt te zijn aan de gehaltes van N, P en $\mathrm{K}$ in het blad.

De re-distributie van stikstof vanuit de vegetatieve delen van de plant naar de generatieve delen zou een van de oorzaken kunnen zijn van bladveroudering en daarmee invloed hebben op de opbrengst (en het eiwitgehalte). Egli et al. (1978) onderzochten onder kasomstandigheden wat het effect was van het onthouden van stikstof aan soja (via de voedingsoplossing) op de re-distributie van stikstof en de veroudering van de plant. Daarbij kwam naar voren dat het onthouden van stikstof tijdens het begin van de peulvullingsfase de afrijping versnelde, de opbrengst reduceerde en het percentage stikstof in het zaad dat afkomstig was van re-distributie verhoogde (van ca. $20 \%$ tot $60 \%$ ). Deze stikstof was vooral afkomstig van de bladeren en de peulwanden. Verhogen van de 
stikstofconcentratie in de voedingsoplossing daarentegen (boven het standaardniveau) tijdens de peulvullingsperiode had geen effect op de gemeten variabelen. De resultaten van dit onderzoek laten zien dat de re-distributie van $\mathrm{N}$ van de vegetatieve plantdelen naar de generatieve delen de veroudering beïnvloeden maar dat ook andere factoren hierbij een rol spelen. Ook laat dit experiment zien dat bij blijvende aanvoer van stikstof, de opbrengst nog verhoogd kan worden.

Hill and Breidenbach (1974) beschreven de veranderingen van het versgewicht, droog gewicht (figuur 2.4) en de hoeveelheid eiwit van zich ontwikkelende sojabonen in de loop van de tijd (figuur 2.5). Het versgewicht van het zaad ontwikkelde zich heel snel in de periode tussen 12 en 34 dagen na de bevruchting. Daarna nam het versgewicht sterk af. Het drooggewicht nam gedurende de gehele zaadvullingsperiode heel constant toe tot ca. 36 dagen na de bevruchting.

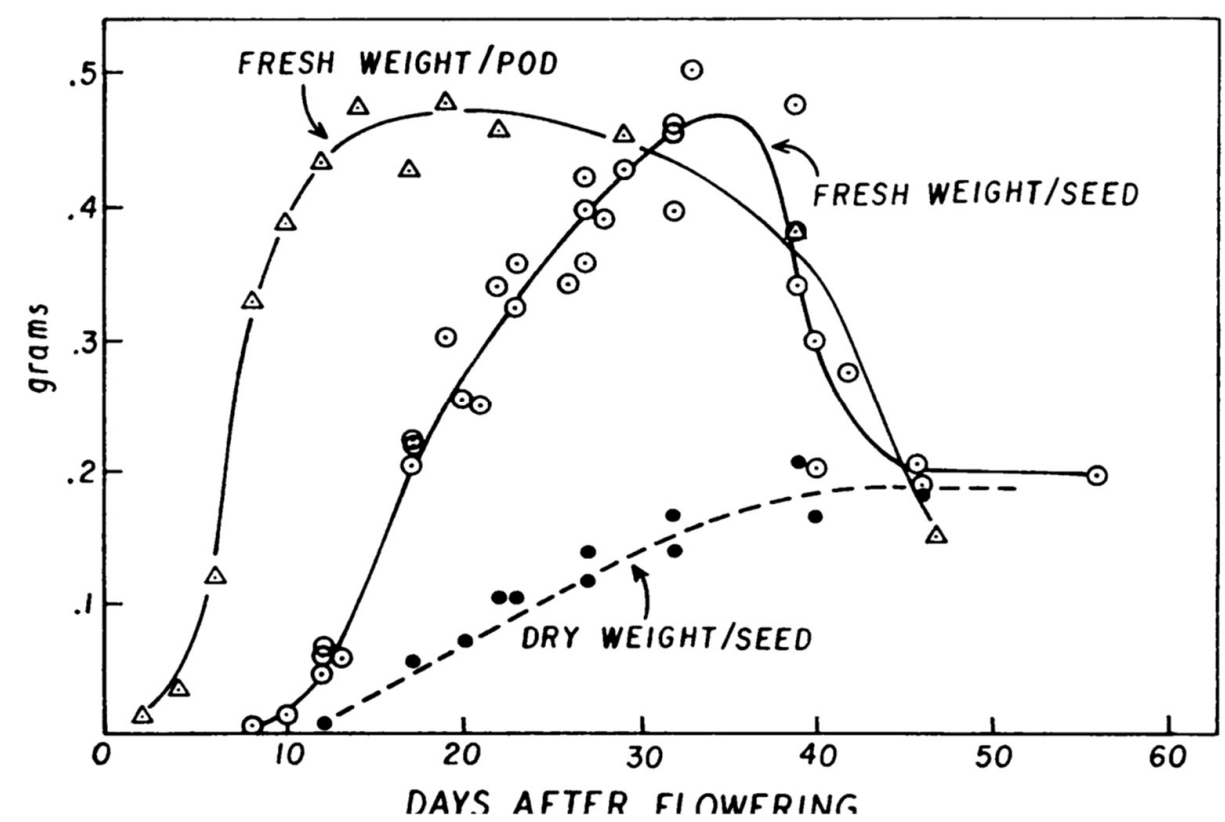

Figuur 2.4 Accumulatie van versgewicht (peul en zaad), droog gewicht (zaad) tijdens zaadvulling en afrijping (bron: Hill and Breidenbach, 1974). 


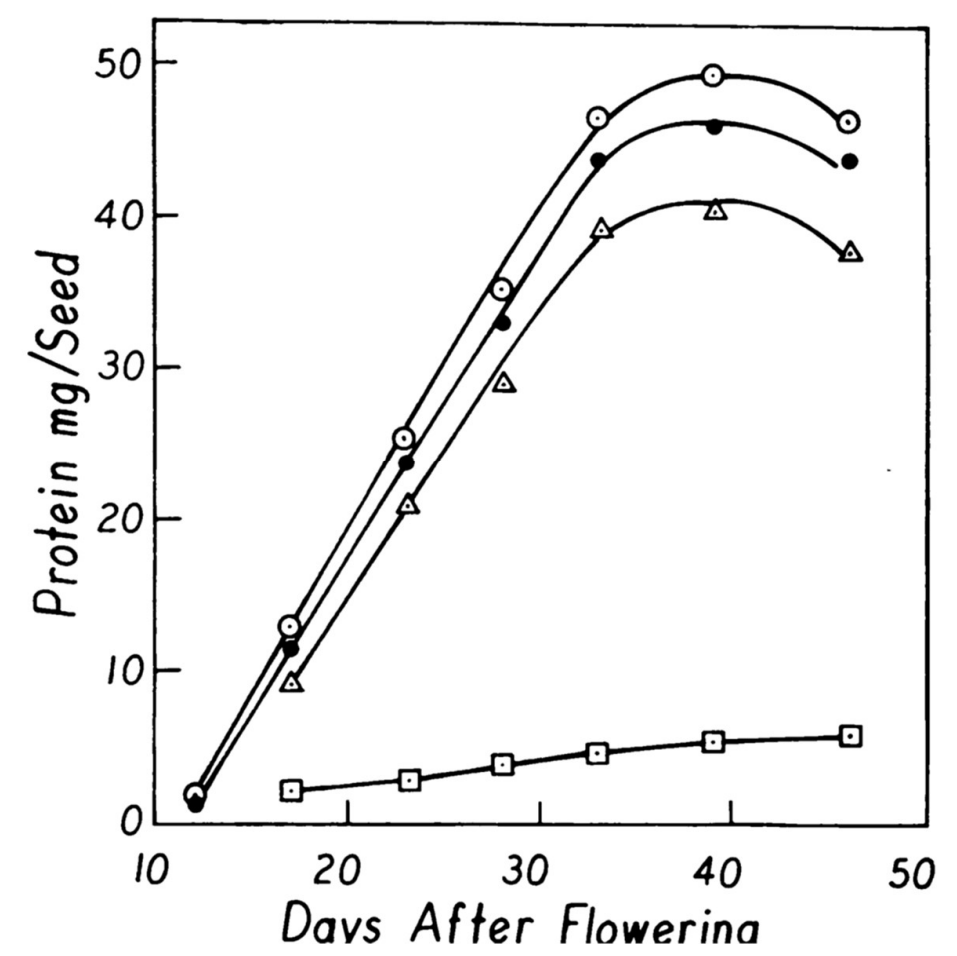

Figuur 2.5 Accumulatie van totaal aan eiwit in het zaad tijdens zaadvulling en afrijping (bovenste lijn). (bron: Hill and Breidenbach, 1974).

Tijdens de zaadvulling en afrijping van het gewas nam de activiteit van de wortelknolletjes af in het experiment van Hill and Breidenbach (1974). Rassen met een hoger eiwitgehalte bleken echter in staat te zijn om langer door te gaan met de $\mathrm{N}$-fixatie tot zelfs in het R6-stadium (full seed). Op deze manier zijn deze rassen in staat om meer stikstof te binden in een later gewasstadium en het eiwitgehalte zo te verhogen (Leffel et al., 1992).

Dit sluit aan bij het onderzoek van Egli and Bruening (2007) die na een 3-jarig onderzoek in Kentucky (VS), tot de conclusie kwamen dat een grotere hoeveelheid $\mathrm{N}$ in het afgerijpte zaad niet gerelateerd was aan een grotere hoeveelheid $\mathrm{N}$ in de vegetatieve massa aan het begin van de zaadvulling. Ofwel, het was niet alleen de redistributie die de hoeveelheid opgeslagen stikstof in het zaad verklaarde. Een mogelijke verklaring voor dit verschijnsel kan zijn dat een hogere $\mathrm{N}$-opname uit de bodem en/of een hogere $\mathrm{N}$-binding gedurende de zaadvullingsperiode (ook) een belangrijke rol spelen.

Onder groeiomstandigheden met voldoende water en een laag organisch stofgehalte in de bodem en weinig N-mineraal, bleek de $\mathrm{N}$-fixatie in een onderzoek van Mastrodomenico and Purcell (2012) door te gaan tot aan het eind van de zaadvullingsperiode en de bron te zijn van ca. $90 \%$ van de hoeveelheid $\mathrm{N}$ in het zaad. Verschillen in de hoeveelheid $\mathrm{N}$ in de vegetatieve delen aan het begin van de zaadvulling bleken in dit onderzoek nauwelijks van invloed op de opbrengst en de $\mathrm{N}$-inhoud van het zaad. $\mathrm{N}$-redistributie had dus een klein aandeel in de $\mathrm{N}$-inhoud van het zaad, terwijl de $\mathrm{N}$ -

beschikbaarheid vanuit de bodem ook zeer beperkt was. De lang actief blijvende knolletjes (tot einde zaadvulling) lijken daarmee het stikstofgehalte te hebben bepaald in opwaartse richting.

De literatuur leert ons dat het eiwit- en daarmee stikstofgehalte in het zaad van soja enerzijds bepaalt wordt door redistributie (en daarmee door de hoeveelheid stikstof in het loof bij begin peulvorming). Maar ook dat als de omstandigheden gunstig zijn voor de vorming en levensduur van de wortelknolletjes na begin peulvorming, de hoeveelheid stikstof kan toenemen onafhankelijk van de stikstofreserve in het loof. Die omstandigheden (genoeg water, gebrek aan minerale stikstof) kunnen dus een sleutel vormen naar een hoger eiwitgehalte in de soja. 
14 | Rapport WPR-833 


\section{N-Behoefte van het gewas}

Een maat voor de $\mathrm{N}$-behoefte van een sojagewas is de hoeveelheid eiwit die in de sojabonen wordt vastgelegd. In Nederland is de gemiddelde zaadopbrengst bij soja over de afgelopen 3-4 jaar zo'n 3 t/ha (bij een vochtgehalte van 15\%). Het daarbij gewenste eiwitgehalte is minimaal $40 \%$. Om dit te kunnen realiseren is een $\mathrm{N}$-opname/ $\mathrm{N}$-vastlegging door het gewas, alleen al voor de bonen, nodig van meer dan $170 \mathrm{~kg} \mathrm{~N}$ per ha. Om de teelt economisch rendabel te maken voor een teler is echter een opbrengst nodig van $4 \mathrm{t}$ per ha. Dit betekent dat bij eenzelfde eiwitpercentage van min. $40 \%$ de hoeveelheid stikstof die door het gewas moet worden opgenomen/vastgelegd, alleen al voor de bonen, meer dan $230 \mathrm{~kg} \mathrm{~N} / \mathrm{ha}$ zou moeten bedragen. En voor de toepassing van sojabonen voor food is eigenlijk een eiwitgehalte nodig van minimaal $42 \%$. Hiermee komt de eerder genoemde minimale $\mathrm{N}$ vastlegging in de bonen op $250 \mathrm{~kg} \mathrm{~N} / \mathrm{ha}$.

In de $\mathrm{N}$-behoefte van een sojagewas wordt voorzien door stikstofopname uit de bodem ( $\mathrm{N}$-min voorraad en mineralisatie) en via $\mathrm{N}$-binding uit de lucht (via de wortelknolletjes). Van de totale $\mathrm{N}$ behoefte is soja in staat om ongeveer $50 \%-75 \%$ te halen uit $\mathrm{N}$-binding, de rest moet komen uit de bodem (Salvagiotti et al., 2008; Ciampitti and Salvagiotti, 2018). Dat kan via mineralisatie en/of door een kunstmestgift aan het gewas te geven.

Volgens Zapata et al. (1987) is de N-behoefte van soja het sterkst (zo'n 4.5-5 kg N/ha/dag) tijdens de R3-R5 fase, de periode waarin de zaadvulling plaatsvindt. De procentuele bijdrage van de $\mathrm{N}$-fixatie in de $\mathrm{N}$-behoefte tijdens die fase was in het onderzoek van de auteurs meer dan $65 \%$.

Het aantal knolletjes en de activiteit daarvan neemt echter af vanaf fase R6. Dit betekent dat er mogelijk aan het eind van het seizoen een $\mathrm{N}$-tekort zou kunnen optreden. Ook wanneer soja groeit onder omstandigheden die hoge opbrengsten toelaten, zou er al eerder een situatie kunnen ontstaan waarin de N-binding en de opname vanuit de bodem de vraag niet kunnen dekken ("N-gap");

(Ciampitti and Salvagiotti, 2018).

\subsection{Stikstofknolletjes}

Soja is in staat om stikstof uit de lucht op te nemen en om te zetten naar een opneembare vorm voor de plant in symbiose met de bacterie Bradyrhizobium japonicum. De Rhizobium-bacteriën krijgen op hun beurt voedingsstoffen (suikers) van de sojaplant. De N-fixatie via de wortelknolletjes levert de plant dus enerzijds stikstof op, maar kost de plant aan de andere kant ook energie.

De bacteriën waarmee soja in symbiose leeft zijn van nature niet aanwezig in de Europese bodems en moeten geïnoculeerd worden bij het zaaien. In Nederland wordt door telers veelal gebruik gemaakt van sojazaden die bij aankoop al geënt zijn met Rhizobium-bacteriën, de zogenaamde "FixFertig"(kant-en-klare) zaden. Hierbij is door de leverancier gekozen voor een bepaald Rhizobiumproduct en voor een dosering. Het is echter ook mogelijk onbehandelde zaden te kopen en deze zelf met Rhizobium te behandelen. Er zijn diverse Rhizobium-producten op de markt en er kan, hoewel er door de fabrikant een adviesdosering wordt meegegeven, ook met de dosering van deze producten gevarieerd worden.

Het blijkt dat de Rhizobium-bacteriën pas actief worden als de bodemtemperatuur voldoende hoog is. In Zwitserland/Duitsland is door FiBL onderzoek gedaan naar dit temperatuurseffect (Messmer et al., 2012). Uit een pottenproef in de kas kwam naar voren dat de ontwikkeling van de wortelknolletjes bij een dag/nacht temperatuur regime van $14 / 10^{\circ} \mathrm{C}$ heel beperkt was (1-3 knolletjes per plant). Terwijl bij een regime van $16 / 12^{\circ} \mathrm{C}$ dit aantal al sterk was verhoogd tot 10 knolletjes of meer. Er leek een activiteitsdrempel te liggen bij een (bodem)temperatuur van $15^{\circ} \mathrm{C}$. Daarbij was er wel een interactie tussen temperatuur en Rhizobiumproduct (sommige producten, zoals de USDA 30-stam, waren 
werkzamer bij lagere temperaturen dan andere) en tussen ras en Rhizobiumproduct (het optimale Rhizobiumproduct verschilde per ras).

Aansluitend op het hiervoor genoemde onderzoek voerde FiBL 3 jaar lang veldonderzoek uit op 2 locaties in Midden Duitsland (omgeving Kassel, Bernburg) met 4 verschillende commercieel verkrijgbare Rhizobium-producten (Radicin No.7, NPPL-Hi Stick, Force 48, Biodoz Rhizofilm). Deze werden getest op 3 rassen (Zimmer et al., 2016). Hierbij kwam naar voren dat inoculatie met Radicin No.7 nauwelijks tot wortelknolletjes leidde. De andere producten gaven alle drie een goede bezetting. De aantallen verschilden van gemiddeld 13 tot 22 knolletjes per plant. Biodoz Rhizofilm gaf gemiddeld het hoogste aantal knolletjes, de hoogste opbrengst en de hoogste eiwitopbrengst. Het eiwitgehalte was bij toepassing van Biodoz gemiddeld bijna 1.5\% hoger dan bij de andere 2 producten. Er was geen interactie met het ras: bij alle drie de rassen was het eiwitgehalte bij Biodoz het hoogste.

Ook op de universiteit van Hohenheim werd de effectiviteit van een aantal Rhizobiumentingsproducten onderzocht (Wächter et al., 2013). Dit gebeurde in een pottenproef in de kas waar zaad van 2 rassen (Merlin en Primus) werd geënt met 5 verschillende producten, één bodem-enting en één combinatie van een bodem-enting en een zaadenting. De producten waren: Force 48, NPPL HiStick, RhizoFlo, NPPL Microgranulés (bodementing), Radicin № 7 en de "kant en klare"-versie van HiStick ("FixFertig"). Het gemiddelde aantal wortelknolletjes varieerde van 5 bij het minst effectieve tot 143 per plant bij het meest effectieve product. Behalve het aantal knolletjes verschilden ook de grootte van de knolletjes en de biomassa aan knolletjes sterk per product. Er bleek daarbij een interactie aanwezig te zijn: de effectiviteit van de (zaad)entingsproducten was significant verschillend bij beide rassen. Gemiddeld was het aantal wortelknolletjes het laagst bij het kant-en-klare zaad (Fix fertig) en bij Radicin No7. NPPL Histick deed het minder bij het ras Merlin. De andere producten verschilden niet significant van elkaar in aantal knolletjes. Een bodementing had bij Merlin een vergelijkbaar effect op het aantal knolletjes als bij een effectieve zaadbehandeling. Bij Primus was het effect van een bodementing minder goed. De combinatie van een bodementing en het fix-fertig zaaizaad had bij beide rassen een vergelijkbaar aantal knolletjes als bij een effectieve zaadenting. Een mogelijke verklaring voor de grote verschillen is het aantal bacteriën in elk product. Dit kan al in de basis verschillend zijn maar kan ook uiteenlopen door de formulering van een product en eventuele toevoegingen (o.a. stickers). Een lange periode tussen de enting en het zaaien kan mogelijk een rol spelen bij een lagere effectiviteit van het "kant en klare" zaad. Wächter et al. (2013) stellen dat om tot een optimale symbiose te komen tussen soja en $B$. japonicum er in elk entingsproduct een groot aantal levende bacteriën aanwezig moet zijn van minstens $10^{9} \mathrm{KbE}$ per $\mathrm{ml}$ (of per $\mathrm{g}$ ).

Omdat het om een pottenproef in de kas ging, is er alleen gekeken naar de ontwikkeling van de knolletjes en de biomassa van de soja, en zijn er geen opbrengsten en eiwitgehalten bepaald. In hoeverre verschillen in knolletjesvorming het eiwitgehalte kunnen beïnvloeden wordt op basis van het onderzoek van Wächter et al. (2000) dus niet duidelijk.

Eerder (2008) werd in Spanje (Sevilla) een veldproef uitgevoerd met toenemende concentraties van Rhizobium bacteriën van 2 verschillende op turf opgekweekte stammen (Assefa et al., 2019). Hierbij werd zaad geïnoculeerd met $10^{4}, 10^{5}, 10^{6}$ en $10^{7}$ Rhizobium-cellen per sojaboon. Hoewel de verschillen klein waren en niet significant, was er een tendens aanwezig dat zowel het aantal wortelknolletjes aan de wortels als de opbrengst en het eiwitgehalte licht toenamen bij een toenemende concentratie aan Rhizobium-cellen. Dit komt overeen met de conclusie van Wächter et al. (2013) die stellen dat een hoge concentratie aan levende Rhizobium-cellen belangrijk is om tot een optimaal resultaat te komen.

In Brazilië is onderzocht of het zinvol is om bij aanwezigheid van een grote populatie van Rhizobiumbacteriën in de grond aanvullend ook het zaad nog te enten. Ook werd nagegaan wat het effect is van een aanvullende bespuiting met Rhizobium tijdens het groeiseizoen (Moretti et al., 2018). Bij deze bespuitingen werd een Rhizobium oplossing in vijf verschillende gewasstadia (V1, V3, V5, R1, R3) aan het eind van de dag op gewas/grond gespoten en vervolgens werd er $10 \mathrm{~mm}$ beregend.

De zaadenting leverde in beide jaren een sterke toename op van het aantal wortelknolletjes per plant (van 13 naar 31 en van 14 naar 25 per plant). De opbrengst nam hierdoor toe met 28 resp. $27 \%$ t.o.v. onbehandeld zaad in een bodem waarin al een hoge populatie met Rhizobium aanwezig was. Door één aanvullende Rhizobium-bespuiting nam bij geënt zaaizaad gemiddeld het aantal 
stikstofknolletjes verder toe van resp. 31 naar 39 en van 25 naar 33 per plant. Hoewel de verschillen tussen de tijdstippen klein waren was het aantal knolletjes in het V6-R1 stadium (begin bloei) iets hoger dan op de andere tijdstippen. De opbrengst nam hierdoor in beide onderzoekjaren toe met resp. $2 \%$ (2015, niet significant) en $7 \%$ (2016, significant). Het eiwitgehalte werd echter in geen van de proeven verhoogd door de Rhizobium-bespuitingen. Dit onderzoek bevestigde eerdere rapportages dat een zaadenting toegevoegde waarde heeft ook al is er een grote Rhizobiumpopulatie in de bodem aanwezig. Noemenswaardiger was echter dat een daarbovenop uitgevoerde gewasbespuiting met Rhizobium het aantal knolletjes aan de wortels en de opbrengst (en daarmee de N-opname) positief beïnvloedde.

Er zijn verschillende methoden om de wortels van een sojaplant in contact te brengen met Rhizobium bacteriën, buiten het feit dat deze al in de bodem aanwezig kunnen zijn. Hardarson and Golbs (1989) deden onderzoek naar verschillende toedieningstechnieken en het effect daarvan op het aantal en de verdeling van de wortelknolletjes over het wortelstelsel, en de invloed daarvan op de N-fixatie. Door verschillende manieren van enting (via zaad, via bodem voor het zaaien en via bodem later in het seizoen) werd een verschillend bezettingspatroon van de wortels met knolletjes bewerkstelligd. Bij een enting via zaaizaad werden veruit de meeste knolletjes gevonden aan de hoofdwortels(s) en in de laag $0-5 \mathrm{~cm}$. Bij mengen van het Rhizobium product door de grond of het aanbrengen op de diepte van het zaaizaad werd een veel betere verdeling over de hoofd en zijwortels verkregen. De positie van de knolletjes aan de wortels beïnvloedde de $\mathrm{N}$-fixatie waarbij knolletjes aan de zijwortels significant meer stikstof vastlegden dan knolletjes aan de hoofdwortel. En ook later gevormde knolletjes hadden een substantieel aandeel in de totale $\mathrm{N}$-fixatie. Conclusie was dat de positie van de knolletjes aan het wortelstelsel belangrijker is dan het aantal knolletjes en/of het drogestof gewicht van de knolletjes. Knolletjesvorming aan de zijwortels en diepere wortels zouden wel eens essentieel kunnen zijn voor een optimale $\mathrm{N}$-fixatie; zeer waarschijnlijk zijn ze van groot belang tijdens de (latere) zaadvullingsfase, een periode waarin de vraag naar stikstof op z'n grootst is. Het inoculeren van de grond i.p.v. het zaad, of als aanvulling op het zaad, lijkt de $\mathrm{N}$-fixatie aanzienlijk te kunnen verhogen. Aangezien in Nederland alleen het zaad wordt geënt is het interessant om de mogelijkheden van een (aanvullende) grondinoculatie te onderzoeken.

\section{Conclusie}

De temperatuurdrempel voor het actief worden van de Rhizobium-bacteriën zou ervoor pleiten om soja in Nederland niet te vroeg in het voorjaar te zaaien omdat de minimaal benodigde $15^{\circ} \mathrm{C}$ bodemtemperatuur in onze streken pas in de loop van mei wordt bereikt. Een andere optie is te kiezen voor een Rhizobium stam die bij lagere temperaturen actiever is dan andere stammen, zoals de USDA 30 stam (Messmer et al., 2012). Bij 6 veldproeven in de periode 2011-2013, met een zaaidatum tussen 20 april en 8 mei kwam Biodoz Rhizofilm als beste naar voren (Zimmer et al., 2016). Het selecteren van het beste Rhizobium product in combinatie met voor Nederland geschikte rassen lijkt een mogelijkheid om tot hogere opbrengsten en een hoger eiwitgehalte te komen. Hiervoor zou een vergelijkbaar onderzoek als Zimmer et al. (2016) beschrijven, uitgevoerd moeten worden in Nederland. Ook in het verhogen van de dosis van het aantal Rhizobium bacteriën bij het enten van het zaad lijkt ruimte te zitten om tot betere resultaten te komen (Albareda et al., 2009; Wächter et al., 2013). Verder lijkt het op basis van de literatuur interessant om te onderzoeken of aanvullende bespuitingen met Rhizobium tijdens het seizoen in Nederland kan leiden tot een hogere opbrengst en/of een hoger eiwitgehalte.

Omdat de bacterie in symbiose leeft met de sojaplant, en de wortelknolletjes behalve stikstof leveren ook voedingsstoffen kosten, zal er een optimaal aantal per plant zijn. Excessieve ontwikkeling van wortelknolletjes zou de plant namelijk teveel energie gaan kosten. Om de kosten en baten in balans te houden bestaat er een zelfregulerend systeem in de sojaplant die de vorming van knolletjes controleert (Tanabata, S. and Ohyama, T., 2014). Naar de werking van dit systeem en welke factoren hierbij een rol spelen wordt onderzoek gedaan. In geen enkel artikel kon echter iets gevonden worden over het optimale aantal wortelknolletjes per plant. Vermoedelijk is het optimale aantal afhankelijk van de groeiomstandigheden en de plaats op het wortelstelsel en speelt ook de activiteit van de knolletjes een rol. 


\section{$3.2 \quad \mathrm{~N}$-bemesting}

In een uitgebreide review van een groot aantal studies die zijn uitgevoerd naar het effect van $\mathrm{N}$ bemesting op de opbrengst van soja concluderen Salvagiotti et al. (2008) dat de natuurlijke N-fixatie door de sojaplant (via wortelknolletjes) samen met de N-bodemvoorraad en de N-mineralisatie, in de meeste gevallen kan voorzien in de $\mathrm{N}$-behoefte en er geen effect is van een $\mathrm{N}$-bemesting. Alleen in sommige gevallen waarin een inoculatie niet goed is gelukt of de bodemomstandigheden niet optimaal zijn voor de activiteit van de wortelknolletjes, kan een N-bemesting een positief effect hebben. Hoge sojaopbrengsten vragen, zeker bij een hoog eiwitgehalte, om een grote hoeveelheid stikstof. Bij een goede inoculatie van het zaad en een hoge activiteit van de knolletjes kan het gewas hierin voorzien. Er zijn echter aanwijzingen dat in situaties met een hoge opbrengstpotentie ( $>5 \mathrm{t} / \mathrm{ha}$ ) een beperkte $\mathrm{N}$-bemesting tot een meeropbrengst kan leiden (Ciampitti and Salvagiotti, 2018). Het meest geschikte moment van toepassing is dan tijdens de peul- en zaadvulling. In het algemeen is een $\mathrm{N}$ bemesting echter niet economisch rendabel.

Net als Salvagiotti et al. (2008) concludeerden Mourtzinis et al. (2018) op basis van een meta-analyse van een groot aantal proeven vanuit alle delen van de VS dat een $\mathrm{N}$-bemesting slechts in een beperkt aantal gevallen een kleine meeropbrengst geeft. In de meeste situaties is alleen de $\mathrm{N}$-binding (en natuurlijke mineralisatie) al voldoende om in de behoefte te voorzien en zijn de verkregen meeropbrengsten door allerlei soorten $\mathrm{N}$-bemesting (basisgift, gedeelde bemesting, bladbemesting etc.) beperkt, niet significant en niet rendabel. Helaas wordt ook in dit artikel niet ingegaan op het effect van een $\mathrm{N}$-bemesting op het eiwitgehalte.

En ook Kaschuk et al. (2016) komen op basis van proeven in 3 verschillende productiegebieden in Brazilië tot de conclusie dat een N-bemesting niet tot een meeropbrengst leidt. Zowel een basisgift als een bijbemesting bij de peulzetting, als een bemesting op beide tijdstippen gaf geen hogere opbrengst dan het referentieobject zonder $\mathrm{N}$-gift (alle objecten bij enting met efficiënte Rhizobium stam). Behalve dat een $\mathrm{N}$-bemesting geen opbrengstverhoging gaf, was er ook nog een sterk negatief effect op zowel het aantal wortelknolletjes per plant als het gewicht aan knolletjes. Ook bij dit onderzoek wordt niet ingegaan op het effect van een $\mathrm{N}$-bemesting op het eiwitgehalte.

Bij het onderzoek van Kaschuk et al. (2016) moet worden opgemerkt dat de opbrengsten in de proeven varieerden van 2.0 tot $2.7 \mathrm{t} / \mathrm{ha}$. Ook andere onderzoekers kwamen tot de conclusie dat bij dit opbrengstniveau de $\mathrm{N}$-binding in vrijwel alle gevallen in staat is om in de $\mathrm{N}$-behoefte te voorzien. Pas bij hogere opbrengsten is het mogelijk dat de N-binding en de opname vanuit de bodem tekort schieten. Maar dan worden er opbrengsten van 2.5 tot 6.5 t/ha bedoeld (Cafaro La Menza et al., 2017) of meer dan 5.0 t/ha (Salvagiotti et al., 2008).

In Ciampitti and Salvagiotti (2018) wordt geschreven over N-opname en N-fixatie. Het blijkt dat bij hoge $\mathrm{N}$-opnames, de $\mathrm{N}$-fixatie een kleiner aandeel heeft. Als hoge opbrengsten bij goed eiwitgehalte betekenen dat de bijdrage van $\mathrm{N}$-fixatie kleiner is, dan is de vraag waar die andere stikstof vandaan moet komen. Deze komt vermoedelijk uit de grond via $\mathrm{N}$-mineralisatie. Als de mineralisatie hapert kan dit betekenen dat de $\mathrm{N}$-opname onvoldoende wordt met als gevolg lagere opbrengsten en eiwitgehaltes.

In Balcarce (Argentinië) en Nebraska (VS) werden in de periode 2014-2016 veldproeven uitgevoerd waarbij werd nagegaan of er bij hoog opbrengende soja (6-8 t/ha) een limiet is waarbij het gewas niet meer in staat is om zelf te voorzien in de behoefte aan stikstof (Cafaro La Menza et al., 2017). In die situatie zou een $\mathrm{N}$-bemesting rendabel kunnen zijn. Hiertoe werden twee teeltsystemen met elkaar vergeleken: optimale irrigatie+geen $\mathrm{N}$-bemesting (zero $\mathrm{N}$ ) en optimale irrigatie+optimale $\mathrm{N}$ voorziening (full $\mathrm{N}$ ). Bij beide systemen werden de zaden geïnoculeerd met het beste product op de markt. In de laatste situatie werd ervoor gezorgd dat het gewas gedurende het seizoen altijd stikstof tot $z^{\prime} n$ beschikking had en de $\mathrm{N}$-voorziening geen limiterende factor was. De opbrengst in de proeven varieerde van 2.5 tot $6.5 \mathrm{t} / \mathrm{ha}$. Het full-N systeem bracht meer op dan het zero- $\mathrm{N}$ systeem. De meeropbrengst was afhankelijk van het gemiddelde opbrengstniveau en nam toe van $0 \mathrm{~kg} / \mathrm{ha}$ bij een opbrengstniveau van ca. $2.5 \mathrm{t} / \mathrm{ha}$ tot $900 \mathrm{~kg} / \mathrm{ha}$ bij een opbrengstniveau van ca. $6 \mathrm{t} / \mathrm{ha}$. 
Ook het eiwitgehalte was hoger in het full-N systeem in vergelijking tot het zero- $\mathrm{N}$ systeem. In het zero- $\mathrm{N}$ systeem daalde het eiwitgehalte bij een toenemende opbrengst terwijl in het full- $\mathrm{N}$ systeem het eiwitgehalte gelijk bleef bij een toenemende opbrengst.

Conclusie was dat stikstof een limiterende factor was onder omstandigheden met een hoge opbrengst. De natuurlijke $\mathrm{N}$-bronnen voor soja ( $\mathrm{N}$-fixatie en $\mathrm{N}$-beschikbaarheid vanuit de bodem) waren in die situatie onvoldoende in staat om in de $\mathrm{N}$-behoefte van het gewas te voorzien. Zowel opbrengst als eiwitgehalte reageerden positief in die situatie op een $\mathrm{N}$-bemesting. Dit sluit aan bij de bevindingen van Ciampitti and Salvagiotti (2018).

De resultaten van het onderzoek van Fabre and Planchon (2000) bevestigen dat de symbiotische stikstofbinding heel belangrijk is voor zowel de opbrengst als het eiwitgehalte van soja. Een efficiënte $\mathrm{N}$-binding is gedurende de gehele reproductiefase, tot aan het eind van de peulvullingsperiode, van invloed op de hoogte van het eiwitgehalte. De hoogte van de opbrengst is vooral in het begin van de reproductiefase gerelateerd aan opname van stikstof uit de bodem; later tijdens de peulvullingsfase is een hoge en efficiënte $\mathrm{N}$-binding van groot belang. Dit zou er op wijzen dat naast een optimale $\mathrm{N}$ binding ook een voldoende beschikbaarheid van stikstof uit de bodem ( $\mathrm{N}$-bemesting) een rol speelt bij de opbrengstvorming.

Leffel et al. (1992) concludeerden dat rassen met een hoger eiwitgehalte in staat bleken om langer door te gaan met de $\mathrm{N}$-fixatie tot het R6-stadium (full seed). Op deze manier waren ze in staat om meer stikstof te binden in een later gewasstadium en het eiwitgehalte zo te verhogen. Dit sluit aan bij de bevindingen van Fabre and Planchon (2000).

Egli and Bruening (2007) kwamen tot de conclusie dat een grotere hoeveelheid $\mathrm{N}$ in het afgerijpte zaad niet altijd gerelateerd was aan een grotere hoeveelheid $\mathrm{N}$ in de vegetatieve massa aan het begin van de zaadvulling. Ofwel, het was niet (alleen) de redistributie die de reden was van een grotere hoeveelheid opgeslagen stikstof in het zaad.

Deze resultaten geven aan dat het dus een samenspel is van een hogere $\mathrm{N}$-opname uit de bodem, redistributie en een lang doorgaande $\mathrm{N}$-fixatie gedurende de zaadvullingsperiode, die de opbrengst en het eiwitgehalte beïnvloeden.

\section{Conclusie}

Veel artikelen die onderzoek naar het effect van N-bemesting bij soja beschrijven gaan alleen in op het effect op de opbrengst. Over het effect op (het verhogen van) het eiwitgehalte is veel minder informatie te vinden.

Ten aanzien van de opbrengst is de algemene conclusie dat de $\mathrm{N}$-binding in het merendeel van de situaties in staat is om in de N-behoefte van het gewas te voorzien (Salvagiotti et al., 2008; Mourtzinis et al., 2018; Kaschuk et al., 2016; Fabre and Planchon, 2000). Echter enkele andere onderzoekers geven aan dat bij een hoog opbrengstniveau een N-tekort kan optreden tijdens de peulvulling omdat de $\mathrm{N}$-binding (samen met $\mathrm{N}$-beschikbaarheid vanuit de bodem) de sterke $\mathrm{N}$ behoefte van het groeiende zaad niet kan dekken. Een N-bemesting in die gewasfase zou zowel voor de opbrengst als voor het eiwitgehalte een (rendabel) positief effect kunnen hebben (Cafaro La Menza et al., 2017; Salvagiotti et al., 2008). 
20 | Rapport WPR-833 


\section{$4 \quad$ Opbrengstniveau}

Bij de teelt van soja is zowel een hoge opbrengst gewenst als een hoog eiwitgehalte en ook een hoog oliegehalte. Hoe opbrengst, eiwitgehalte en oliegehalte elkaar beïnvloeden is grotendeels onbekend. In Canada zijn in de periode 1998-2000 in een totaal van 13 veldproeven die sterk varieerden in opbrengstniveau, deze relaties onderzocht (Yin and Vyn, 2005). Hierbij kwam naar voren dat het oliegehalte licht negatief was gecorreleerd met het opbrengstniveau maar dat de relatie tussen opbrengst en eiwitgehalte neutraal was. De auteurs stellen dat hoge soja opbrengsten mogelijk zijn zonder een substantiële afname van het eiwitgehalte (en het oliegehalte). Ofwel, het opbrengstniveau was niet of nauwelijks van invloed op de gehaltes aan eiwit en olie en de onderlinge verhouding tussen eiwit en olie.

In de VS (Indiana) werd in de periode 1996-1997 bij veredelingsonderzoek een groep van 43 sojaboon-lijnen onderzocht op de relatie opbrengst, eiwit, olie en koolhydraten (Wilcox and Shibles, 2001). Hoewel het onderzoek met name gericht was op de relatie tussen eiwitgehalte en koolhydraten (zowel zetmeel als suikers) kwam hierbij ook naar voren dat er een significante negatieve relatie was tussen het opbrengstniveau en het eiwitgehalte. Dus een hogere opbrengst betekende een lager eiwitgehalte. Maar aangezien het eiwitgehalte en oliegehalte sterk negatief gecorreleerd waren betekende dit ook een hoger oliegehalte. Veredeling op een hoog opbrengstniveau lijkt daarmee ook te selecteren op een hoog oliegehalte (en een hoge olieopbrengst) en een lager eiwitgehalte. Een hoger eiwitgehalte ging in het onderzoek van Wilcox and Shibles (2001) ten koste van zowel het oliegehalte als het gehalte aan koolhydraten (met name suikers). Deze sterke inverse relatie tussen eiwit en olie wordt ook door verschillende andere onderzoekers genoemd maar is moeilijk te rijmen met de resultaten van Yin and Vyn (2005).

Er lijkt daarbij overigens wel een verschil te zijn tussen de groeitypen "determinate" en "indeterminate". Het determinate-type ontwikkelt zich eerst vegetatief (met een beperkte lengte) en daarna bloeien alle bloemen tegelijkertijd. Het indeterminate-type begint onderin de plant te bloeien en blijft daarna verder groeien en bloemen ontwikkelen. Deze rassen zijn relatief lang.

Bij determinate lijnen werden wel combinaties gevonden van een hoge opbrengst en een hoog eiwitgehalte, bij indeterminate lijnen niet (Wilcox and Zhang, 1997). Deze resultaten duiden erop dat determinate-lijnen een betere selectiebron zijn om een hoge opbrengst te combineren met een hoog eiwitgehalte. De rassen die in Nederland en Europa worden geteeld zijn indeterminate.

In Oostenrijk werden van 1993 t/m 1998 een groot aantal soja-lijnen onderzocht op opbrengst en eiwit- en oliegehalte (Vollmann et al., 2000). De 5 groeiseizoenen verschilden sterk van elkaar in hoeveelheid neerslag, neerslagverdeling en de temperatuur tijdens verschillende groeifases. De gemiddelde opbrengst varieerde van 1.8 tot 3.0 t/ha. Het eiwitgehalte varieerde van $30 \%-43 \%$ en het oliegehalte van $17 \%$ tot $25 \%$. Er bleek in 5 van de 6 jaar een significante negatieve correlatie tussen opbrengst en eiwitgehalte. In alle jaren was er ook een zeer sterke negatieve correlatie tussen oliegehalte en eiwitgehalte. Grotere hoeveelheden neerslag gedurende de peulvullingsperiode gingen in het onderzoek van Vollmann et al. (2000) samen met een laag eiwitgehalte en een daaraan gekoppeld hoger oliegehalte. De grotere hoeveelheid neerslag verlengde de periode tot afrijping en de lengte van deze periode had een negatieve relatie met het eiwitgehalte. Hoewel het eiwitgehalte per seizoen sterk verschillend was bleek de ranking van een aantal standaardrassen op basis van het eiwitgehalte constant over de jaren. De variatie in het eiwitgehalte werd door de auteurs vooral verklaard door het jaar (groeiomstandigheden). De hoogste eiwitgehalten werden in het Oostenrijkse onderzoek bereikt in jaren met weinig neerslag en hogere temperaturen gedurende het gehele groeiseizoen. Dit leidde tot een kortere afrijpingsperiode.

Vollmann et al. (2000) concluderen ook dat het mogelijk is om bij de veredeling te selecteren op vroegrijpende sojatypen met een hoog eiwitgehalte. Dit wordt volgens de auteurs alleen beperkt door de negatieve correlatie tussen opbrengst en eiwitgehalte. 
Rotundo et al. (2009) evalueerden de relatie tussen zaadsamenstelling bij de oogst en de voorziening met assimilaten per zaad/boon bij nauw gerelateerde, experimentele lijnen die verschilden in eiwitgehalte. Een hoger eiwitgehalte bleek samen te gaan met een groter bladoppervlak dat per geproduceerde boon beschikbaar was. Dit laatste was een gevolg van minder bonen per plant gecreëerd door het wegnemen van een deel van de peulen. Het wegnemen van peulen tijdens de zaadvulling bij de lijnen met een laag eiwitgehalte vergrootte de gemiddelde zaadgrootte en verhoogde het eiwitgehalte tot een niveau vergelijkbaar met dat van de "onbehandelde" lijnen met hoog eiwitgehalte. Bij de lijnen met een hoog eiwitgehalte had het wegnemen van peulen veel minder effect op de zaadgrootte. Dit suggereert dat lijnen met een hoog eiwitgehalte de assimilatie per boon kunnen handhaven op of rond de vraag naar assimilaten tijdens de zaadvulling. Om het eiwitgehalte van hoog opbrengende rassen te verhogen is volgens de auteurs (Rotundo et al., 2009) een grotere assimilatenvoorziening nodig per boon zonder dat dit ten koste gaat van het aantal bonen.

\section{Conclusie}

Literatuur over de relatie tussen opbrengst en eiwitgehalte geeft een wat wisselend beeld. Er wordt enerzijds gemeld dat hogere opbrengsten niet tot significant lagere eiwitgehalten leidt (Yin and Vyn, 2005) maar anderzijds zijn er meerdere artikelen die aangeven dat een hoge opbrengst wel gecorreleerd is met een lager eiwitgehalte (Wilcox and Zhang, 1997; Wilcox and Shibles, 2001; Vollmann et al., 2000). Over het algemeen wordt aangenomen dat er een negatieve relatie is tussen opbrengst en eiwitgehalte. Rotundo et al. (2009) komen tot de conclusie dat een grotere voorziening met assimilaten per boon nodig is om het eiwitgehalte te verhogen bij hoog-opbrengende rassen. 


\section{Weersomstandigheden groeiseizoen}

Ook in landen waar van oudsher grote hoeveelheden soja worden geproduceerd (VS, Brazilië, Argentinië) fluctueert het eiwitgehalte sterk. Het meerjarige gemiddelde eiwitgehalte in de VS ligt rond de $40 \%$ maar kan variëren per ras, regio en jaar van 30\% tot wel 48\% (Brumm and Hurburgh, 2006). Weersomstandigheden tijdens het groeiseizoen spelen hierbij een rol.

Bij een onderzoek in Australië kwam naar voren dat toenemende droogte tijdens de peulvullingsfase niet alleen leidt tot lagere opbrengsten maar ook tot een hoger eiwitgehalte en een lager oliegehalte (Rose, 1988). Dit sluit aan bij de resultaten van Vollmann et al. (2000) die meldden dat de variatie in het eiwitgehalte in hun onderzoek voor het grootste deel verklaard werd door de factor Jaar (groeiomstandigheden). De hoogste eiwitgehalten werden in dit onderzoek bereikt onder relatief droge(re) omstandigheden en hogere temperaturen tijdens de peulvullingsperiode welke samen gingen met een lagere opbrengst. Hogere temperaturen tijdens de peulvullingsperiode hadden een toename van het eiwit+olie\% tot gevolg bij een analyse van 20 jaar rassenproeven in de VS (Piper and Boote, 1999). Bij een toenemende gemiddelde dagtemperatuur nam het oliegehalte toe en het eiwitgehalte (licht) af.

Eigen ervaringen met Nederlandse soja in het droge en warme jaar 2018 zijn moeilijk in overeenstemming te brengen met bovenstaande indicaties uit de literatuur. In 2018 kende de soja in het noordoosten van Nederland over de gehele linie een verrassend laag eiwitgehalte (34\%) bij een lage opbrengst (2,2 ton per ha). In het zuidoosten bereikten we een hoge opbrengst van circa 4,5 ton per ha met een laag eiwitgehalte van circa 37\%. Deze resultaten onderschrijven niet de conclusies van bovenstaande auteurs. Wellicht dat de langdurige droogte geleid heeft tot een beperkte mineralisatie in de afrijpingsfase. Het jaar 2019 kenmerkte zich in Nederland door warmte en droogte in de zomer met een erg nat slot dat ook resulteerde in een erg late oogst van de soja. De opbrengsten waren met 3,5-4 ton per ha goed met een eiwitgehalte dat in het Noorden onder de $40 \%$ bleef maar in het Zuiden richting 44-45\% ging. Dit verschil tussen de regio's is moeilijk te verklaren maar wellicht had dit te maken met een toenemende mineralisatie tijdens de natte eindfase van de teelt.

In Iowa (VS) werden in 1985 en 1986 kasproeven uitgevoerd waarin het effect werd onderzocht van temperatuurstress of droogtestress als ook een combinatie van beide (Dornbos and Mullen, 1992). Een hogere temperatuur tijdens de periode van peulvulling had in dit onderzoek een hoger eiwitgehalte tot gevolg en ook droogtestress leidde tot een hoger eiwitgehalte. De combinatie van beide deed het eiwitgehalte nog sterker toenemen. Zowel de droogtestress als de temperatuurstress hadden ook een sterke reductie van de opbrengst tot gevolg. Lagere opbrengsten door stress gingen samen met hogere eiwitgehalten (en lagere oliegehalten).

In 4 proeven in India varieerde het eiwitgehalte bij 7 sojarassen van $32 \%$ tot $42 \%$ (Kumar et al., 2006). Er waren significante verschillen in eiwitgehalte tussen de 4 proeflocaties, tussen de 7 rassen en ook was er een significante interactie ras $\mathrm{x}$ locatie. Het onderzoek bevestigde de conclusie van andere onderzoekers (Rose, 1988; Dornbos and Mullen, 1992) die aangaven dat een hogere gemiddelde dagtemperatuur tijdens de peulvullingsfase een positieve correlatie heeft met eiwitgehalte (en een negatieve correlatie met oliegehalte). Neerslag had een negatieve correlatie met het eiwitgehalte.

Rotundo and Westgate (2009) voerden een meta-analyse uit naar de effecten van groeiomstandigheden, met name watertekort, temperatuur en $\mathrm{N}$-bemesting, op het eiwit- en oliegehalte van soja. Zij kwamen tot de conclusie dat zowel watertekort als een hoge temperatuur weliswaar de hoeveelheid eiwit per boon ( $\mathrm{mg} /$ zaadje) reduceerde maar dat het eiwitgehalte (in \% van de ds) toenam. De oorzaak hiervan was een sterkere afname van de hoeveelheid olie en overige inhoudsstoffen in het zaad dan van eiwit. Door de relatief beperktere afname van de hoeveelheid eiwit nam het percentage eiwit toe. De periode waarin het watertekort optrad had wel effect op de 
resultaten. Een watertekort gedurende de gehele groei verlaagde alle zaadcomponenten (eiwit, olie, overige inhoudsstoffen) in min of meer dezelfde mate. Hierdoor werden de percentages niet significant beïnvloed. Watertekort later in de zaadvullingsperiode (R5-R8) verlaagde echter de hoeveelheid eiwit (veel) minder dan die van olie en de overige inhoudsstoffen. Dit verschil resulteerde in een significante verhoging van het eiwitgehalte.

Een hogere temperatuur verlaagde de hoeveelheid eiwit, olie en overige inhoudsstoffen in de meeste gevallen, maar in mindere mate dan bij watertekort. Ook bij een hogere temperatuur was de afname van de hoeveelheid eiwit (per boon) minder sterk dan van olie en de overige inhoudsstoffen. Hierdoor nam per saldo het percentage eiwit toe.

Het effect van een $\mathrm{N}$-bemesting op het eiwitgehalte in veldproeven was heel beperkt (gemiddeld $+1 \%$ punt over alle studies). Er was echter een tendens dat het effect groter was bij een hogere $\mathrm{N}$-gift. Ook was het effect iets groter bij een $\mathrm{N}$-gift aan het begin van de peulvullingsfase (R1-R4).

In geen enkel geval werd het oliegehalte en het gehalte aan overige inhoudsstoffen door $\mathrm{N}$ bemestingen (significant) beïnvloed.

Een periode van lichte tot matige droogte bleek het aantal wortelknolletjes en ook het gewicht aan wortelknolletjes niet of nauwelijks te beïnvloeden. Bij droogtestress nam het aantal knolletjes in de periode vanaf volledige lichtonderschepping in dezelfde mate toe als bij een beregend object (Sinclair et al., 1988). De N-fixatie werd door droogte wel gereduceerd en in een sterkere mate dan de afname van de fotosynthese (Sinclair et al., 1987). Dit zou kunnen betekenen dat de plant onder drogere omstandigheden meer afhankelijk wordt van de opname van $\mathrm{N}$ uit de bodem omdat de activiteit van de wortelknolletjes afneemt. En wanneer er onvoldoende stikstof in de bodem beschikbaar is kan dit de opbrengst en het eiwitgehalte beperken.

\section{Conclusie}

De hoeveelheid neerslag en de gemiddelde dagtemperatuur tijdens de peulvullingsfase hebben effect op de opbrengst en het olie- en eiwitgehalte van soja. Hogere temperaturen en (toenemende) droogte gaan veelal samen met een lagere opbrengst, een hoger eiwitgehalte en een lager oliegehalte (Rose, 1988; Vollmann et al., 2000; Dornbos and Mullen, 1992; Kumar et al., 2006). Alleen Piper and Boote (1999) komen in hun onderzoek tot de conclusie dat het eiwitgehalte eerder afneemt dan toeneemt bij hogere temperatuur tijdens de peulvullingsfase.

Het eiwitgehalte en het oliegehalte zijn sterk negatief gecorreleerd. Dit komt in diverse onderzoeken duidelijk naar voren. Daar waar oliegehalten hoog zijn, zijn de eiwitgehalten veelal laag/lager, en omgekeerd.

Het eiwitgehalte van soja wordt bepaald door het ras, de teeltwijze, de teeltomstandigheden en de interactie tussen deze 3 factoren. De diverse studies naar de invloed van weerfactoren, zoals temperatuur, zonlicht en neerslag op de groei en samenstelling van sojabonen laten een wisselend beeld zien. Sommige studies rapporteren een toename van het oliegehalte bij een hogere temperatuur zonder een effect op het eiwitgehalte (Mourtzinis et al., 2018), terwijl andere studies (Kumar et al., 2006) een positieve, lineaire relatie laten zien tussen temperatuur en eiwitgehalte, maar een negatieve relatie tussen temperatuur en oliegehalte. Weer andere studies vinden een positief effect van hogere temperaturen op zowel het eiwitgehalte als het oliegehalte. Dit gaat dan wel samen met een lage(re) opbrengst.

Toenemende droogte beperkt de productiviteit van het gewas maar de activiteit van de N-knolletjes neemt nog sterker af (Sinclair et al., 1987). Een hypothese is dat afhankelijk van de beschikbare hoeveelheid stikstof in de bodem hierdoor het eiwitgehalte kan toenemen (bij relatief veel stikstof in de bodem) of afnemen (bij weinig stikstof in de bodem). 


\section{Literatuur}

Albareda, M., Rodríguez-Navarro, D.N., Temprano, F.J., 2009. Soybean inoculation: Dose, N fertilizer supplementation and rhizobia persistence in soil. Field Crops Research (113), 352-356.

Assefa Y, Purcell, L.C., Salmeron, M., Naeve, S., Casteel, S.N., Kovács, P., Archontoulis, S., Licht, M., Below, F., Kandel, H., Lindsey, L.E., Gaska, J., Conley, S., Shapiro, C., Orlowski, J.M., Golden, B.R., Kaur, G., Singh, M., Thelen, K., Laurenz, R., Davidson, D., Ciampitti, I.A., 2019. Assessing variation in US soybean seed composition (protein and oil). Frontiers in Plant Science (11), March 2019.

Brumm, T.J., Hurburgh, C.R., 2006. Changes in Long-Term Soybean Compositional Patterns. Journal of the American Oil Chemists' Society (83), 981-983.

Cafaro La Menza, N., Monzon, J.P., Specht, J.E., Grassini, P., 2017. Is soybean yield limited by nitrogen supply? Field Crops Research (213), 204-212.

Ciampitti, A., Salvagiotti, F., 2018. New Insights into Soybean Biological Nitrogen Fixation. Agronomy Journal (110), 1185-1196.

Dornbos, D.L., Mullen, R.E., 1992. Soybean seed protein and oil contents and fatty acid composition adjustments by drought and temperature. Journal of the American Oil Chemist's Society 69 (3), 228-231.

Egli, D.B., Leggett, J.E., Duncan, W.G., 1978. Influence of N-stress on leaf senescence and $\mathrm{N}$-redistribution in soybeans. Agronomy Journal Abstract (70), 43-47.

Egli, D.B., Bruening, W.P., 2007. Nitrogen accumulation and redistribution in soybean genotypes with variation in seed protein concentration. Plant Soil (301), 165-172.

Fabre, F., Planchon, C., 2000. Nitrogen nutrition, yield and protein content in soybean. Plant Science 152, 51-58.

Hardarson, G., Golbs, M., 1989. Nitrogen fixation in soybean as affected by nodulation patterns. Soil Biology and Biochemistry Vol. 21, Issue 6, 783-787.

Hill, J.E., Breidenbach, R.W., 1974. Proteins of soybean seeds. Plant Physiology (53), 747-751.

Kaschuk, G., Nogueira, M.A., Javier de Luca, M., 2016. Response of determinate and indeterminate soybean cultivars to basal and topdressing $\mathrm{N}$ fertilization compared to sole inoculation with Bradyrhizobium. Field Crops Research (195), 21-27.

Kumar, V. Rani, A., Solanki, S., Hussain, S.M., 2006. Influence of growing environment on the biochemical composition and physical characteristics of soybean seed. Journal of Food Composition and Analysis 19 (Issues 2-3), 188-195.

Leffel, R.C., Cregan, P.B., Bolgiano, A.P., Thibeau, D.J., 1992. Nitrogen metabolism of normal and high-seed-protein soybean. Crop Science Abstract Vol. 32, No. 3, 747-750.

Mastrodomenico, A.T., Purcell, L., 2012. Soybean nitrogen fixation and nitrogen remobilization during reproductive development. Crop Science Society of America (52) No. 3, 1281-1289.

Messmer, M., Berset, E., Zimmer, S., Haase, T., Habekuss, A., Paláez, S., Hertenstein, F., Thonar, C., Salomé, C., Ordon, F., Hess, J., Wilbois, K.P., 2012. Breeding for improved soybean bradyrhizobia symbiosis for cool growing conditions in central Europe. http://orgprints.org/21797/ (Poster at: 10th European Nitrogen Fixation Conference).

Moretti, L.G., Lazarini, E., Bossolani, J.W., Parente, T.L., Caioni, S., Araujo, R.S., Hungria, M., 2018. Can additional inoculations increase soybean nodulation and grain yield? Agronomy Journal (110), 715-721

Mourtzinis, Kaur, G., Orlowski, J.M., Shapiro, C.A., Lee, C.D., Wortmann, C., Holshouser, D., Nafziger, E.D., Kandel, H., Niekamp, J., Ross, W.J., Lofton, J., Vonk, J., Roozeboom, K.L., Thelen, K.D., Lindsey, L.E., Staton, M., Naeve, S.L., Casteel, S.N., Wiebold, W.J., Conley, S.P., 2018. Soybean response to nitrogen application across the United States: A synthesisanalysis. Field Crops Research (215), 74-82.

Piper, E.L., Boote K.I., 1999. Temperature and cultivar effects on soybean seed oil and protein concentrations. Journal of the American Oil Chemist's Society (76), 1233-1241. 
Rose, I.A. (1988). Effects of moisture stress on the oil and protein components of soybean seeds. Australian Journal of Agricultural Research 39 (2), 163-170.

Rotundo, J.L., Borrás, L., Westgate, M.E., Orf, J.H., 2009. Relationship between assimilate supply per seed during seed filling and soybean seed composition. Field Crops Research (112), 90-96. 



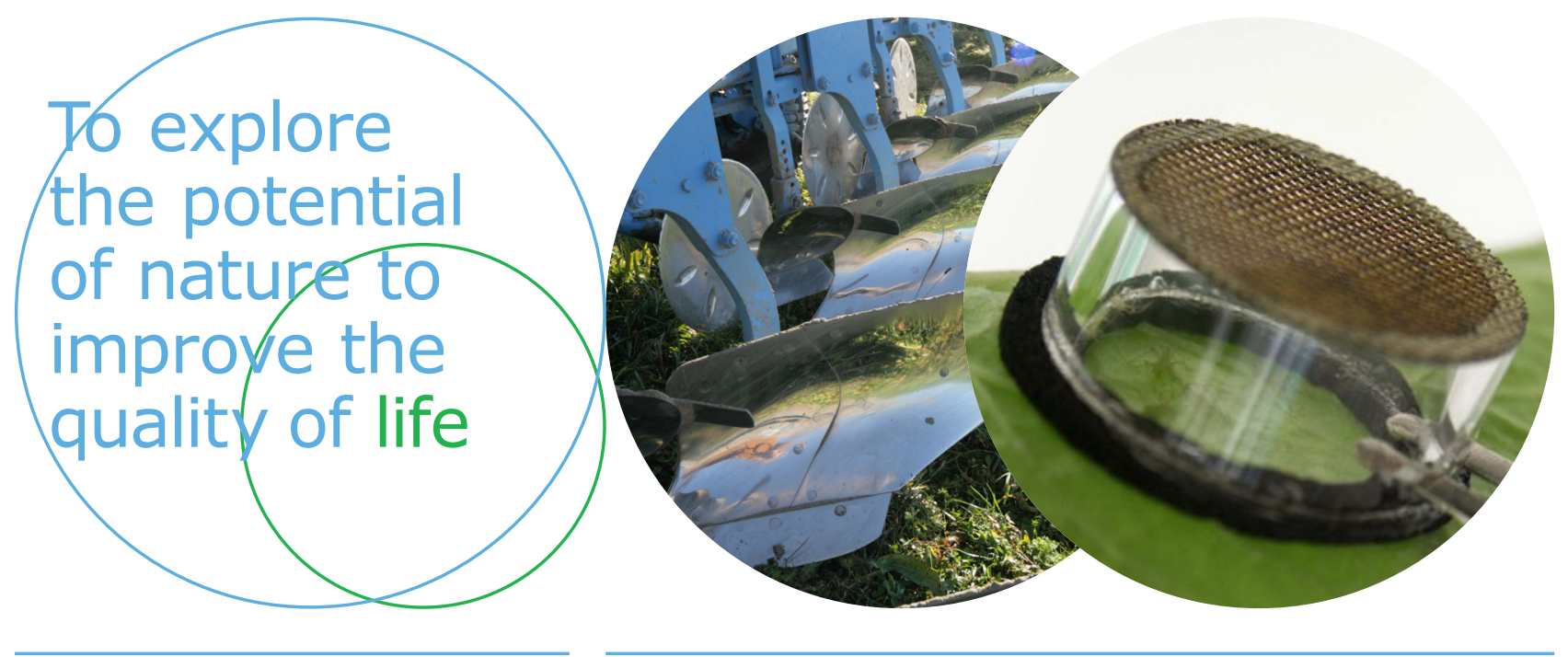

Correspondentie adres voor dit rapport: Wageningen University \& Research | Open Teelten

Edelhertweg 1

Postbus 430

8200 AK Lelystad

$\mathrm{T}(+31) 320291111$

www.wur.nl/openteelten

Rapport WPR-833
De missie van Wageningen University \& Research is 'To explore the potential of nature to improve the quality of life'. Binnen Wageningen University \& Research bundelen 9 gespecialiseerde onderzoeksinstituten van stichting DLO en Wageningen University hun krachten om bij te dragen aan de oplossing van belangrijke vragen in het domein van gezonde voeding en leefomgeving. Met ongeveer 30 vestigingen, 6.000 medewerkers en 9.000 studenten behoort Wageningen University \& Research wereldwijd tot de aansprekende kennisinstellingen binnen haar domein.

De integrale benadering van de vraagstukken en de samenwerking tussen verschillende disciplines vormen het hart van de unieke Wageningen aanpak.

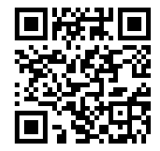

